\title{
Physiochemical and Sensory Evalution of some Bakery Products Supplemented with Unripe Banana Flour as a Source of Resistant Starch Mona M. Khalil ${ }^{1}$; M. M. Tabikha ${ }^{1}$; M. H. Hosny ${ }^{2}$ and A. A. Kortam ${ }^{1}$ \\ ${ }^{1}$ Food Industries Dept - Fac. of Agric., Mansoura Univ. , Egypt \\ ${ }^{2}$ Food Technology Res. Inst., Agric. Res. Center, Giza, Egypt.
}

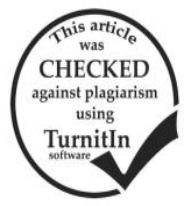

\section{ABSTRACT}

Unripe banana flour (UBF) is a starchy food that contains a high proportion of indigestible compounds as resistant starch (RS), and non-starch polysaccharides. Therefore this study was designed to examine the effect of adding unripe banana flour as a source of resistant starch to prepare some bakery products such as cupcake and flat bread of high nutritional quality. The effect of wheat flour substituted with unripe banana flour at the levels of 10, 20,30,40, and 50\% were investigated in terms of the physicochemical and Sensory evaluation of cupcake and flat bread. Sensory evaluation revealed that successful replacement of cupcake samples was found at levels 10, 20 and 30\% unripe banana flour ( contained 10.44, 17.93 and 21.05\% RS). While flat bread samples with10, 20 and 30\% unripe banana flour (contained $11.19,18.62$ and 21.02\% RS).Obtained results indicated that specific volume reduced with the increasing level of unripe banana flour . Texture profile analysis showed that replacement of wheat flour by unripe banana flour increased hardness and cohesiveness. But resilience, springiness, chewiness and gumminess were decreased of processed cupcake samples. On the other hand the increasing level of unripe banana flour added to wheat flour caused increasing hardness, and decreasing in springiness, gumminess, and chewiness of flat bread. So it can be suggested that unripe banana flour can be used up to $30 \%$ in preparation of bakery products such as cupcake and flat bread with good sensory and physicochemical properties

Keywords: unripe banana flour, resistant starch, cupcake, flat bread

\section{INTRODUCTION}

According to the Food and Agriculture Organization of the United Nations and because of high bread consumption, Egypt is the largest wheat importer worldwide Gazette; (2013) Most of the domestic production of wheat goes into rural household consumption, where most farmers use the wheat flour to bake their own bread. Egypt imported 10,593,506 tons of wheat in addition to the consumption of the domestic production Boutros, (2013).

The most important factor for considering unripe bananas as a prebiotic food is its resistant starch content, characterized by the portion of the granule or its degradation products that are not digested or absorbed in the small intestine and are fermented in the large intestine Acevedo et al; (2012).

New economical strategy to increase utilization of banana includes the production of banana flour when the fruit is unripe and to incorporate the flour into various innovative products such as slowly digestible cookies Aparicio-Saguilan, et al; (2007) Few studies have evaluated the effect of adding of unripe banana flour to bread Pacheco-Delahaye and Testa,( 2005), Juarez-Garcia et al; ( 2006), Zuleta et al; ( 2012) El Marassy et al; (2016)

According to various resistant starch (RS) types, (RS2) is found in the native uncooked granules of some starches such as those in unripe bananas and raw potatoes Englyst et al (1992). .Aparicio- Saguilán et al; (2007) found that a resistant starch rich powder prepared from unripe banana flour was a potential ingredient for bakery products containing slowly digestible carbohydrate.

Cupcakes are the most consumed bakery product owing to unique products and are always used in festivals as well as in joyous celebrations .Hafez, (2012).

Flat bread is simple bread made from flattened dough of flour, salt, water, yeast and other optional ingredients.. Additional (optional) ingredients may be used for processing aids which are essential in particular in the bread-making process, in improving the quality and for fortification of bread to have more nutritive value eggs, milk, other legumes, cereals, dried fruits and unripe banana, and be added to the formula of the bread AlDmoor, (2012)

So, this work was aimed to study the effect of adding unripe banana flour at different levels as a source of resistant starch on organolepticlal texture, chemical and physical properties of cake and flat bread.

\section{MATERIALS AND METHODS}

\section{Materials:}

Raw materials:

Green banana fruits (grand Nan) unripe banana were purchased from one of the banana plantations in Sadat City, Egypt. At first stage of maturation (approximately 110-120 days after bloom)

\section{Other materials:}

Wheat flour (72\%), margarine, sugar, eggs ,salt, yeast, baking powder dried skim milk and vanilla, were obtained from local market of tanta City, Egypt .

Chemicals:

All chemicals (analytical grade) were purchased from sigma company for medical materials, El- Gizah , Egypt.

Methods:

Preparation of raw materials:

Unripe Banana Flour was prepared according to the method described by Tiboonbun et al ; (2011) Fruits were peeled and then cut into $0.2 \mathrm{~cm}$ slices and then rinsed in citric acid solution $(0.3 \% \mathrm{w} / \mathrm{v})$. The slices were dried at $50^{\circ} \mathrm{C}$ in a hot air oven (Mechanical Dehydrator, HI-Tech Equipments, India) and then milled using a laboratory electronic mill (BRAWN, Model 2001 DL, Germany) and sifted through 100-mesh screen and stored in airtight poly ethylene bags at $\left(15 \pm 2^{\circ} \mathrm{C}\right)$ for further uses.

\section{Preparation of cupcakes:}

The cupcake processing method was taken according to Dubat ; (2010) the conventional method of all dry ingredients and eggs were weighted using an electronic scale accurate to $0.1 \mathrm{~g}$. The flour, baking powder, dried skim milk and vanilla were sifted together in a medium mixing bowl. A handled electric 
mixer (Moulinex model supermix 150) was used at a speed 3 for all mixing steps. The margarine was creamed for 1 min and the sugar and salt was added and mixing was continued for an additional 1 min. Eggs was then added to the creamed mixture and all were mixed for an additional $2 \mathrm{~min}$ on third of dried mixture and water was added and all were mixed for 45 second, this was repeated twice. The batter was poured into aluminum cup. The baked cupcakes were cooled down at room temperature, then packed into aluminum foil bags and stored at room temperature. And simultaneously presented to the panelists.

The basic formulae of cupcake and composite of flour cakes are outlined in Table (1).

Table 1. Formulation of different cupcake samples .

\begin{tabular}{lccccccccc}
\hline $\begin{array}{l}\text { Ingredients(g) } \\
\text { Samples }\end{array}$ & $\begin{array}{c}\text { WF } \\
\mathbf{7 2 \%}\end{array}$ & UBF & Sugar & Salt & Egg & Margarine & $\begin{array}{c}\text { Skimed milk } \\
\text { bowder }\end{array}$ & $\begin{array}{c}\text { Baking } \\
\text { bowder }\end{array}$ & Vanilla \\
\hline Control & 250 & - & 125 & 3.5 & 110 & 53.5 & 25 & 12.5 & 2 \\
$10 \%$ UBF & 225 & 25 & 125 & 3.5 & 110 & 53.5 & 25 & 12.5 & 2 \\
$20 \%$ UBF & 200 & 50 & 125 & 3.5 & 110 & 53.5 & 25 & 12.5 & 2 \\
$30 \%$ UBF & 175 & 75 & 125 & 3.5 & 110 & 53.5 & 25 & 12.5 & 2 \\
$40 \%$ UBF & 150 & 100 & 125 & 3.5 & 110 & 53.5 & 25 & 12.5 & 2 \\
$50 \%$ UBF & 125 & 125 & 125 & 3.5 & 110 & 53.5 & 25 & 12.5 & 2 \\
\hline
\end{tabular}

UBF: Unripe banana flour WF: Wheat flour

\section{Preparation of flat bread:}

flat bread was prepared according Faridi and Rubenthaler ; (1984)).where bread making involved mixing $100 \mathrm{~g}$ wheat flour $(72 \%)$, yeast $(1 \% \mathrm{w} / \mathrm{w})$ salt $(1.5 \% \mathrm{w} / \mathrm{w})$, and $75 \mathrm{ml}$ water. Ingredients were mixed until the dough was developed, then the resulted dough was let to rest for $10 \mathrm{~min}$ then divided. The pieces of dough were placed on a try sprinkled with a thin layer of wheat and let to ferment for $40 \mathrm{~min}$. at $30 \pm 2{ }^{\circ} \mathrm{C}$ and $85 \%$ relative humidity (final proofing). The pieces were then flattened to about $20 \mathrm{~cm}$ diameters and baked directly at $450-500^{\circ} \mathrm{C}$ for $60-120 \mathrm{sec}$ in a pilot plant oven .After baking, loaves were allowed to cool at room temperature before sealed in polyethylene bags to prevent moisture loss then storage at room temperature $\left(18 \pm 2^{\circ} \mathrm{C}\right)$ until further analysis and evaluation were carried out . The basic formulae of flat bread are outlined in Table (2).

Table 2. Formulation of different flat bread samples

\begin{tabular}{lccccc}
\hline $\begin{array}{l}\text { Ingredient } \\
\text { (g) }\end{array}$ & $\begin{array}{c}\text { Wheat } \\
\text { flour } \\
\text { Samples }\end{array}$ & $\begin{array}{c}\mathbf{7 2 \%} \\
\text { Unripe } \\
\text { banana } \\
\text { flour }\end{array}$ & Salt & Yeast & Water \\
\hline control & 100 & - & 1.5 & 1 & 75 \\
$10 \%$ UBF & 90 & 10 & 1.5 & 1 & 75 \\
$20 \%$ UBF & 80 & 20 & 1.5 & 1 & 75 \\
$30 \%$ UBF & 70 & 30 & 1.5 & 1 & 75 \\
$40 \%$ UBF & 60 & 40 & 1.5 & 1 & 75 \\
$50 \%$ UBF & 50 & 50 & 1.5 & 1 & 75 \\
\hline
\end{tabular}

UBF: Unripe banana flour

Physical analysis of Cupcakes:

Physical properties of cupcake as volume $\left(\mathrm{c} \mathrm{m}^{3}\right)$, weight $(\mathrm{g})$, specific volume and height $(\mathrm{cm})$ were determined according to A.A.C.C.,(1994)

Sensory evaluation of Cupcakes:

Cupcakes were judged for appearance (10), crust color(10), crumpcolor(10), volume(10), texture(15), grain( 15), odor(15), taste(15)and overall ascore (100) by ten panelists as described in A.A.C.C.,(1994)

Sensory evaluation of flat bread:

The sensory of flat bread was carried out according to the method of El-Farra et al ; (1982). The scores for various attributes were crust color (15), description of crust (15), crumb color (15), crumb appearance (15), separation of layer (15), taste (15), odor (10) and overall ascore (100).

The average of total score was converted to a descriptive category as follows:

Very good $\quad 90: 100$

Good $80:<90$

Satisfactory Less than 80

Texture profile analysis:

Texture profile analysis was determined according to Gomes et al,(2006), by a QC-Tech-B type texture analyzer (Taiwan) provided with the software "texture Expert" an aluminum $25 \mathrm{~mm}$ diameter cylindrical probe (flat ended) was used in a " Texture profile analysis" (TPA). Double compression test to penetrate to $50 \%$ depth was applied at speed test of 1 $\mathrm{mm} / \mathrm{sec}$. with a 30 second delay between first and second compression. The measured parameters were hardness, cohesivenees , springiness , gummines , chewiness and resilience for cupcake. While hardness, springiness, gummines and chewiness by newton for flat bread.

\section{Analytical methods:}

Gross chemical composition :

Moisture, crude protein, fat, crude fiber and ash were determined according to the method of the A.O.A.C (2007)

The percentage of total carbohydrate were calculated by difference

Determination of resistant starch (RS):

RS contents of the raw materials and treated samples were determined according to the method described by Eerlingen et al. (1994).

Statistical analysis:

Data were analyzed using SPSS by one way analysis of variance (ANOVA). A multiple comparison of treatment means was performed by Duncan's new multiple range test according to Steell and Torrie (1980) ,significance of the differences was defined at $\mathrm{P}<0.05$.

\section{RESULTS AND DISCUSSION}

\section{Chemical composition of wheat flour and unripe banana flour:}

Wheat flour (72\%) and unripe banana flour. were analyzed for their chemical composition. Such as moisture, crude protein, fat, ash, crude fiber and total 
carbohydrates. The obtained results are shown in Table.(3)

Table 3. Chemical composition of wheat flour and unripe banana flour (DWB).

\begin{tabular}{lllll}
\hline Parameters & $\begin{array}{l}\text { Moistu Crude Fat } \\
\text { re }\end{array}$ & $\begin{array}{l}\text { Ash } \\
\text { protei } \%\end{array} \%$ & $\begin{array}{l}\text { Crude Total } \\
\text { fiber carbohydrat }\end{array}$
\end{tabular}

\begin{tabular}{|c|c|c|}
\hline Material & $\begin{array}{l}\text { fiber } \\
\%\end{array}$ & $\begin{array}{l}\text { carbohydrat } \\
\text { es* } \\
\%\end{array}$ \\
\hline
\end{tabular}

\begin{tabular}{lllllll}
\hline Wheat & 11.25 & 11.20 & 0.99 & 0.66 & 0.42 & 86.73
\end{tabular}

flour $72 \%$

$\begin{array}{lllllll}\text { Unripe } & 12.05 & 4.20 & 0.43 & 2.50 & 6.30 & 86.57\end{array}$

banana flour

DWB : On dry weight basis

* Total carbohydrates was calculated by differences

It could be observed that wheat flour $(72 \%)$ contained $11.25 \%$ moisture, $11.2 \%$ protein , $0.99 \%$ fat , $0.66 \%$ ash , $0.42 \%$ of crude fiber and $86.73 \%$ carbohydrates. While unripe banana flour contained $12.05 \%$ moisture, $4.2 \%$ crude protein , $0.43 \%$ fat , 2.5 $\%$ ash, $6.3 \%$ crude fiber and $86.57 \%$ of total carbohydrates. The obtained data are nearly agreement with Seleem and Omran., (2014) who found that protein , fat ,ash, fiber and total carbohydrates of wheat flour (72\%) $11.21 \%, 1.26 \%, 0.7 \%, 1 \%$ and $75,3 \%$ respectively also The chemical composition unripe banana flour was nearly agreement with Bezerra et al., (2013) who obtained that protein, fat, ash , fiber and carbohydrates were $4.41 \%, 0.45 \%, 1.08 \%, 8.49 \%$ and $86.9 \%$ on dry weight basis.

\section{Resistant starch content of Wheat flour and Unripe banana flour}

Results illustrated in Table (4) show resistant starch content of wheat flour and unripe banana flour. Obtained results indicate that unripe banana flour had the highest resistant starch content(53.12\%)in compared to wheat flour $(11.72 \%)$.these results are in accordance with Ritthiruangdej et al .,(2011) who recorded that
(RS) in unripe banana flour was $56.17 \%$ but Menezes et al., (2011) recorded $48.99 \%$ and Bezerra et al., (2013) that were $40.14 \%$ in unripe banana flour.

Table 4. Resistant starch content of Wheat flour (72\%) and unripe banana flour materials (DWB).

\begin{tabular}{lc}
\hline Material & Resistant starch (\%) \\
\hline Wheat flour (72\%) & 11.72 \\
Unripe banana flour & 53.12 \\
\hline (DWB): On dry weight basis &
\end{tabular}

\section{(DWB): On dry weight basis}

Sensory evaluation of processed cupcake:

Tabulated results in Table (5) show organoleptic properties of cupcake samples made from wheat flour (72) and unripe banana flour. The data indicated that control sample which contained $100 \%$ wheat flour $(72 \%)$ recorded the highest total acceptability value of 92.5 ,followed by samples $\mathrm{No}(1),(2),(3),(4)$ and (5) they recorded $91.5,90.12$ $, 81.37,77.25$ and 71.5 respectively. It could be concluded that non-significant differences were observed in texture, grains, odor and overall score among cupcake samples contained $10 \%, 20 \%$ unripe banana flour compared with control sample made from $100 \%$ wheat flour, also nonsignificant differences were observed in appearance, crust color ,crumb color and volume between control and samples $\mathrm{No}(1)$. While there were significantly differences between samples (3),(4),(5)and control in appearance, crust color , crumb color, volume, texture ,grains, odor, taste and overall score .On the other hand control sample recorded the highest value in appearance, crust color , crumb color and volume compared to the other samples which recorded 9.12, $9.37,9$, and 9.5 respectively. While sample No (2) was the most score in texture, grains, odor and taste which recorded 14.25, 14.37, 14.62 and 14.75 , respectively. It could be observed that increasing the level of added unripe banana flour reduced over all acceptability of cupcake.

Table 5. Sensory evaluation of cupcake made from wheat flour with or without different levels of unripe banana flour.

\begin{tabular}{|c|c|c|c|c|c|c|c|c|c|c|c|}
\hline $\begin{array}{l}\text { Sensory } \\
\text { Cupcak }\end{array}$ & $\begin{array}{l}\text { valuation } \\
\text { amples }\end{array}$ & $\begin{array}{c}\text { Appearance } \\
\text { (10) }\end{array}$ & $\begin{array}{c}\text { Crust } \\
\text { Color } \\
(10)\end{array}$ & $\begin{array}{c}\text { Crumb } \\
\text { color } \\
(10)\end{array}$ & $\begin{array}{l}\text { Volume } \\
\text { (10) }\end{array}$ & $\begin{array}{c}\text { Texture } \\
\text { (15) }\end{array}$ & $\begin{array}{c}\text { Grains } \\
\text { (15) }\end{array}$ & $\begin{array}{l}\text { Odor } \\
\text { (15) }\end{array}$ & $\begin{array}{c}\text { Taste } \\
\text { (15) }\end{array}$ & $\begin{array}{c}\text { Over all } \\
\text { score } \\
(100)\end{array}$ & $\begin{array}{l}\text { Overall } \\
\text { score } \\
\text { category }\end{array}$ \\
\hline control & & $\begin{array}{c}9.12 \pm 0.64 \\
\mathrm{a}\end{array}$ & $\begin{array}{c}9.37 \pm 0.51 \\
\mathrm{a}\end{array}$ & $\begin{array}{c}9 \pm 0.53 \\
\mathrm{a}\end{array}$ & $\begin{array}{c}9.5 \pm 0.53 \\
\mathrm{a}\end{array}$ & $\begin{array}{c}14 \pm 0.75 \\
\mathrm{ab}\end{array}$ & $\begin{array}{c}14.12 \pm 0.64 \\
\text { ab }\end{array}$ & $\begin{array}{l}3.75 \pm .46 \\
\mathrm{ab}\end{array}$ & $\begin{array}{c}.87 \pm 0 \\
\mathrm{bc}\end{array}$ & $\begin{array}{c}92.75 \pm 1.75 \\
\mathrm{a}\end{array}$ & VG \\
\hline 1 & $10 \% \mathrm{UBF}$ & $\begin{array}{c}8.62 \pm 0.74 \\
\mathrm{ab}\end{array}$ & $\begin{array}{c}8.75 \pm 0.46 \\
a b\end{array}$ & $\begin{array}{c}8.5 \pm 0.53 \\
a b\end{array}$ & $\begin{array}{c}8.62 \pm 0.51 \\
a b\end{array}$ & $\begin{array}{c}14.37 \pm 0.74 \\
\mathrm{a}\end{array}$ & $\begin{array}{c}14.12 \pm 0.35 \\
a b\end{array}$ & $\begin{array}{c}14.25 \pm 1.16 \\
\mathrm{ab}\end{array}$ & $\begin{array}{c}14.25 \pm 0.7 \\
a b\end{array}$ & $\begin{array}{c}91.5 \pm 1.06 \\
\mathrm{a}\end{array}$ & VG \\
\hline 2 & $20 \% \mathrm{UBF}$ & $\begin{array}{c}8 \pm 0.53 \\
\text { bc }\end{array}$ & $\begin{array}{c}8.12 \pm 0.64 \\
b\end{array}$ & $\begin{array}{c}8.12 \pm 0.35 \\
b\end{array}$ & $\begin{array}{c}7.87 \pm .64 \\
\text { bc }\end{array}$ & $\begin{array}{c}14.25 \pm 0.7 \\
\mathrm{a}\end{array}$ & $\begin{array}{c}14.37 \pm 0.74 \\
\text { a }\end{array}$ & $\begin{array}{c}14.62 \pm 0.51 \\
\mathrm{a}\end{array}$ & $\begin{array}{c}14.75 \pm 0.46 \\
\mathrm{a}\end{array}$ & $\begin{array}{c}90.12 \pm 1.95 \\
\mathrm{a}\end{array}$ & VG \\
\hline 3 & $30 \%$ & $\begin{array}{c}7.37 \pm 0.74 \\
\mathrm{c}\end{array}$ & $\begin{array}{c}7 \pm 0.75 \\
\mathrm{c}\end{array}$ & $\begin{array}{c}6.75 \pm 1.03 \\
\mathrm{c}\end{array}$ & $\begin{array}{c}7 \pm 0.75 \\
\mathrm{c}\end{array}$ & $\begin{array}{c}13.37 \pm 0.91 \\
\text { bc }\end{array}$ & $\begin{array}{c}13.12 \pm 1.24 \\
\mathrm{~b}\end{array}$ & $\begin{array}{c}13.37 \pm 0.91 \\
\text { b }\end{array}$ & $\begin{array}{c}13.37 \pm 0.51 \\
\mathrm{~cd}\end{array}$ & $\begin{array}{c}81.37 \pm 3.24 \\
\text { b }\end{array}$ & G \\
\hline 4 & $40 \% \mathrm{UBF}$ & $\begin{array}{c}6.62 \pm 0.91 \\
\mathrm{~d}\end{array}$ & $\begin{array}{c}6.37 \pm 0.74 \\
\mathrm{c}\end{array}$ & $\begin{array}{c}6.37 \pm 0.51 \\
\mathrm{c}\end{array}$ & $\begin{array}{c}7.12 \pm 1.12 \\
\mathrm{c}\end{array}$ & $\begin{array}{c}12.62 \pm 0.74 \\
\mathrm{c}\end{array}$ & $\begin{array}{c}413.37 \pm 0.91 \\
\mathrm{ab}\end{array}$ & $\begin{array}{c}11.75 \pm 0.46 \\
\mathrm{c}\end{array}$ & $\begin{array}{c}13 \pm 1.06 \\
\mathrm{~d}\end{array}$ & $\begin{array}{c}77.25 \pm 3.53 \\
\mathrm{c}\end{array}$ & S \\
\hline 5 & $\begin{array}{l}50 \% \text { UBF } \\
\text { L.S.D }\end{array}$ & $\begin{array}{c}6.37 \pm 0.74 \\
\mathrm{~d} \\
1.97\end{array}$ & $\begin{array}{c}5 \pm 0.53 \\
\mathrm{~d} \\
1.59\end{array}$ & $\begin{array}{c}5.5 \pm 0.53 \\
\mathrm{~d} \\
1.68\end{array}$ & $\begin{array}{c}7.37 \pm 1.5 \\
\mathrm{c} \\
2.48\end{array}$ & $\begin{array}{c}11.5 \pm 0.92 \\
\mathrm{~d} \\
2.16\end{array}$ & $\begin{array}{c}12 \pm 1.3 \\
\mathrm{c} \\
2.52\end{array}$ & $\begin{array}{c}11.62 \pm 1.5 \\
\mathrm{c} \\
2.51\end{array}$ & $\begin{array}{c}12.12 \pm 0.64 \\
\mathrm{e} \\
1.89\end{array}$ & $\begin{array}{c}71.5 \pm 4.24 \\
\mathrm{~d} \\
7.71\end{array}$ & S \\
\hline
\end{tabular}

Values followed by the different letter in the same column are significantly different at: $(\mathrm{p}<0.05)$.

UBF: Unripe banana flour VG: Very good G: Good S: Satisfactory

Generally, control and samples No (1) and (2) had very good categories. While samples No (3) had good categories. However samples No (4) and (5) had satisfactory category.

\section{Physical properties of cupcake products:}

The effect of replacement wheat flour( $72 \%)$ with unripe banana flour on physical properties of cupcake samples hight, volume, weight and specific volume was presented in Table (6). 
The results cleared that control cupcake sample was higher in all physical properties parameters than other processed samples.

Table 6. Physical properties of cupcakes made from wheat flour with or without different levels of unripe banana flour.

\begin{tabular}{|c|c|c|c|c|c|}
\hline \multicolumn{2}{|c|}{$\begin{array}{l}\text { Parameters } \\
\text { Cupcake samples }\end{array}$} & $\begin{array}{c}\text { Height } \\
\text { (cm) }\end{array}$ & $\begin{array}{c}\text { Volume } \\
\left(\mathrm{cm}^{3}\right)\end{array}$ & $\begin{array}{c}\text { Weight } \\
\text { (g) }\end{array}$ & $\begin{array}{l}\text { Specific } \\
\text { volume }\end{array}$ \\
\hline \multicolumn{2}{|c|}{$\begin{array}{l}\text { Control } \\
\text { wheat flour } 72 \%\end{array}$} & $6.7^{\mathrm{a}}$ & $167^{\mathrm{a}}$ & $62.81^{\mathrm{a}}$ & $2.65^{\mathrm{a}}$ \\
\hline 1 & $10 \% \mathrm{UBF}$ & $6.6^{\mathrm{a}}$ & $166^{\mathrm{a}}$ & $62.51^{\mathrm{a}}$ & $2.65^{\mathrm{a}}$ \\
\hline 2 & $20 \% \mathrm{UBF}$ & $6.5^{\mathrm{ab}}$ & $165^{\mathrm{a}}$ & $62.49^{\mathrm{a}}$ & $2.64^{\mathrm{a}}$ \\
\hline 3 & $30 \% \mathrm{UBF}$ & $6.3^{\mathrm{abc}}$ & $163^{\mathrm{a}}$ & $62.62^{\mathrm{a}}$ & $2.61^{\mathrm{ab}}$ \\
\hline 4 & $40 \% \mathrm{UBF}$ & $6.1^{\mathrm{bc}}$ & $161^{\mathrm{b}}$ & $62.79^{\mathrm{a}}$ & $2.56^{\mathrm{bc}}$ \\
\hline 5 & $50 \% \mathrm{UBF}$ & $5.9^{c}$ & $158^{\mathrm{b}}$ & $62.91^{\mathrm{a}}$ & $2.51^{\mathrm{c}}$ \\
\hline
\end{tabular}

From the same Table (6) it can be concluded that no significant differences between control, samples No .(1), (2) and No .(3) in hight, volume , weight and specific volume .Also no significant differences between sample $\mathrm{No}(4)$ and (5) for all physical properties which recorded (6.1, $5.9,161,158,62.79,62.91,2.65,2.51)$ for hight, volume , weight and specific volume respectively. Also, the data showed that control sample have been recorded the highest value for hight,volume,weight and specific volume (6.7, $167,62.81$ and 2.65 , respectively).
Generally. It could be seen that specific volume reduced with the increasing level of unripe banana flour.

From the previous data of physical properties and sensory evaluation it could be concluded that using up to $30 \%$ level of unripe banana flour was suitable for producing cupcakes with good quality.

Results in Table (7) illustrated the chemical composition of cupcake made from wheat flour $72 \%$ with $10 \%, 20 \%$ and $30 \%$ unripe banana flour.

The results indicated that moisture content have been recorded the highest value in cupcake sample No.(3) (41.82\%) followed by sample No.(2)(41.22\%), sample (1)(40.61\%) and control (40.11\%).

The crude protein and fat content of cupcake sample No.(1), (2) and (3) decreased with increasing levels unripe banana flour .they recorded 13.61,12.75, $12.68,20.34,19.93$ and $19.32 \%$, respectively.

On the other hand ash and crude fiber content of cupcake sample No.(1), (2) and (3) increasing with increasing levels unripe banana flour they recorded $1.59,1.65,1.75,1.39,2.10$ and $2.47 \%$, respectively. While control sample was recorded 1.43 and $0.87 \%$, respectively for ash and crude fiber

Total carbohydrate of cupcake samples showed that sample $\operatorname{No}(3)$ had the highest value $63.78 \%$ in compared with other samples No.(2),(1) and control which recorded 63.57, 63.07 and $61.33 \%$,respectively.

Table 7. Chemical composition of cupcake containing wheat flour with or without different levels of unripe banana flour (DWB).

\begin{tabular}{|c|c|c|c|c|c|c|}
\hline $\begin{array}{c}\text { Parameters } \\
\text { Cupcake samples }\end{array}$ & $\begin{array}{c}\text { Moisture } \\
\% \%\end{array}$ & $\begin{array}{c}\text { Crude Protein } \\
\% \%\end{array}$ & $\begin{array}{c}\text { Fat } \\
\%\end{array}$ & $\begin{array}{c}\text { Ash } \\
\%\end{array}$ & $\begin{array}{c}\text { Crude Fiber } \\
\%\end{array}$ & $\begin{array}{c}\text { Total Carbohydrate* } \\
\%\end{array}$ \\
\hline Wheat flour $72 \%$ (control) & 40.11 & 14.88 & 21.49 & 1.43 & 0.87 & 61.33 \\
\hline $10 \% \mathrm{UBF}$ & 40.61 & 13.61 & 20.34 & 1.59 & 1.39 & 63.07 \\
\hline $20 \% \mathrm{UBF}$ & 41.22 & 12.75 & 19.93 & 1.65 & 2.10 & 63.57 \\
\hline $30 \% \mathrm{UBF}$ & 41.82 & 12.68 & 19.32 & 1.75 & 2.47 & 63.78 \\
\hline
\end{tabular}

UBF: Unripe banana flour (DWB) On dry weight basis.

* Total carbohydrates was calculated by differences.

Resistant starch contents of cupcake made from wheat flour with or without different levels of unripe banana flour are presented in Table (8).

Table 8. Resistant starch content of cupcakes made from wheat flour with or without different levels of unripe banana flour.

\begin{tabular}{lcc}
\hline Cupcakes samples & Resistant starch\% \\
\hline Wheat flour $72 \%$ (control) & 6.52 \\
1 & $10 \%$ unripe banana flour & 10.44 \\
2 & $20 \%$ unripe banana flour & 17.93 \\
3 & $30 \%$ unripe banana flour & 21.05 \\
\hline
\end{tabular}

The obtained data clearly revealed that the content of resistant starch was increased considerably as increasing of unripe banana flour added. Where control sample recorded $6.52 \%$. While samples No.(1),(2) and (3) recorded (10.44,17.93 and 21.05) respectively. The results obtained from this analysis are in the same line with those reported by Bhatawal e et al; (2012) in which the relationship between resistant starch content and unripebanana flour substitution was directly proportional.

The results in Table (9) cleared that control cupcake sample was higher in resilience, springiness, chewiness and gumminess than other cake which recorded $(0.34,0.76,0.64$ and $0.97(\mathrm{~N})$, respectively. while they recorded $0.19,0.16$, $0.73,0.57,0.62,0.53,0.81$ and $0.72(\mathrm{~N})$ )for samples No.(1) and (2), respectively.

Table 9. Texture analysis of cupcake made from wheat flour with or without different levels of unripe banana flour

\begin{tabular}{lccccccc}
\hline $\begin{array}{l}\text { Parameters } \\
\text { Cupcake samples }\end{array}$ & $\begin{array}{c}\text { Hardness } \\
(\mathbf{N})\end{array}$ & $\begin{array}{c}\text { Resilience } \\
(\mathbf{N})\end{array}$ & $\begin{array}{c}\text { Cohesiveness } \\
(\mathbf{N})\end{array}$ & $\begin{array}{c}\text { Springiness } \\
(\mathbf{N})\end{array}$ & \multicolumn{2}{c}{ Chewiness Gumminess } \\
$(\mathbf{N})$ & $\mathbf{( N )}$ \\
\hline control & 1.52 & 0.34 & 0.55 & 0.76 & 0.64 & 0.97 \\
$1 \quad$ 20\%UBF & 1.54 & 0.19 & 0.57 & 0.73 & 0.62 & 0.81 \\
$2 \quad 30 \%$ UBF & 1.59 & 0.16 & 0.61 & 0.57 & 0.53 & 0.72 \\
\hline
\end{tabular}


On the other hand, samples (2) was the highest in hardness and cohesiveness compared with other samples. The obtained results are in the same line with those reported by Norhidayah,et al (2014) who mentioned that when replacement unripe banana flour to formulation of cookies had increased the hardness.

Sensory evaluation of flat bread samples:

The organoleptic properties of flat bread are illustrated in Table (10). It could be seen that control sample recorded the highest overall score (95.75).

Processed flat bread samples were sensory evaluated for different properties crust color, description of crust, crump color, crump appearance, separation of layer, taste, odor and overall score.

Data showed that control sample recorded a highest scores of crust color, description of crust, crump color, crump appearance, separation of layer, taste, odor and overall score $(14.37,14.5,14.5,14.25,14.12,14.5$, 9.5 , and 95.75), respectively were recorded for control sample followed by processed cake samples No. (1), (2) and (3).On the other hand other flat bread samples,
No. (4) and (5) recorded the lowest scores for the same properties.

From Table (6), that no significant differences between control, samples No. (1) and No. (2) in crust color, description of crust, crump color, crump appearance, separation of layer, taste, odor and overall score at $\mathrm{P}<0.05$. Also, there were no significantly differences between samples no. (4) and (7) at $\mathrm{P}<0.05$ in description of crust, crump color, crump appearance, taste and odor.

Generally, control and samples Noland 2 had very good categories and scored 95.75, 93.5 and 92 respectively. While samples No 3 had good categories since overall scores recorded were 82.28. However samples No (4) and (5) had satisfactory category which recorded 74.37 and 69.25 , respectively.

So, according to obtained results of above studies of sensory evaluation of different flat bread mixtures samples, it was decided to select samples, No 1, 2 and 3 beside control due to their high acceptability to continue different analysis and evaluations.

Table 10. Sensory evaluation of flat bread made from wheat flour with or without different levels of unripe banana flour.

\begin{tabular}{|c|c|c|c|c|c|c|c|c|c|}
\hline $\begin{array}{l}\text { Sensory } \\
\text { evaluation } \\
\text { Bread samples }\end{array}$ & $\begin{array}{c}\text { Crust } \\
\text { color } \\
(15) \\
\end{array}$ & $\begin{array}{l}\text { Description } \\
\text { of crust } \\
\text { (15) }\end{array}$ & $\begin{array}{c}\text { Crump } \\
\text { color } \\
(15)\end{array}$ & $\begin{array}{c}\text { Crump } \\
\text { appearance } \\
(15)\end{array}$ & $\begin{array}{c}\text { Separation } \\
\text { of layer } \\
\text { (15) }\end{array}$ & $\begin{array}{c}\text { Taste } \\
\text { (15) }\end{array}$ & $\begin{array}{c}\text { Odor } \\
\text { (10) }\end{array}$ & $\begin{array}{c}\text { Overall } \\
\text { score } \\
(100)\end{array}$ & $\begin{array}{l}\text { Over all } \\
\text { category }\end{array}$ \\
\hline Wheat flour(control) & $\begin{array}{c}14.37 \pm 0.51 \\
\mathrm{a}\end{array}$ & $\begin{array}{c}14.5 \pm 0.53 \\
\mathrm{a}\end{array}$ & $\begin{array}{c}14.5 \pm 0.53 \\
\mathrm{a}\end{array}$ & $\begin{array}{r}14.25= \\
a\end{array}$ & $\begin{array}{c}14.12 \pm 0.64 \\
\mathrm{a}\end{array}$ & $\begin{array}{r}14.5 \pm 0 \\
\mathrm{a}\end{array}$ & $\begin{array}{l}5 \pm 0.53 \\
\mathrm{a}\end{array}$ & $\begin{array}{c}95.75 \pm 0.7 \\
a\end{array}$ & VG \\
\hline $110 \% \mathrm{UBF}$ & $\begin{array}{r}14.25 \pm \\
\mathrm{a}\end{array}$ & $\begin{array}{r}14.5 \pm \\
\mathrm{a}\end{array}$ & $\begin{array}{r}14.12 \pm \\
\mathrm{a}\end{array}$ & $\mathrm{a}$ & $\begin{array}{r}13.62 \pm \\
\mathrm{a}\end{array}$ & $13.75 \pm$ & $9.25 \pm 0$ & $\begin{array}{c}93.5 \pm 1.77 \\
\mathrm{a}\end{array}$ & VG \\
\hline $220 \% \mathrm{UBF}$ & $\begin{array}{c}13.62 \pm 0.91 \\
\mathrm{ab}\end{array}$ & $\begin{array}{r}12.75 \pm \\
b\end{array}$ & $\begin{array}{r}14.5 \pm 0 \\
\mathrm{a}\end{array}$ & $\begin{array}{r}14.25 \pm \\
\mathrm{a}\end{array}$ & $\begin{array}{r}13.75+ \\
\mathrm{a}\end{array}$ & $\begin{array}{c}14.37 \pm 0 \\
a b\end{array}$ & $\begin{array}{r}8.75 \pm 0 \\
\mathrm{a}\end{array}$ & $\begin{array}{l} \pm 2.67 \\
\mathrm{a}\end{array}$ & VG \\
\hline $330 \%$ & $\begin{array}{c}12.85 \pm 1.06 \\
\mathrm{~b}\end{array}$ & $\begin{array}{c}11.85 \pm 1.34 \\
\text { bc }\end{array}$ & $12.57 \pm 0.78$ & $12.14 \pm 1.34$ & $12.57 \pm$ & $12.85 \pm 0.89$ & $\begin{array}{c}7.42 \pm 1.27 \\
b\end{array}$ & $\begin{array}{c}82.28 \pm 6.07 \\
b\end{array}$ & G \\
\hline $4 \quad 40 \%$ & $\begin{array}{c}11.12 \pm 1.24 \\
\mathrm{c}\end{array}$ & $11.75 \pm 0.7$ & $10.5 \pm 1.3$ & $\begin{array}{c}10.5 \pm 1.69 \\
\mathrm{c}\end{array}$ & $\begin{array}{c}11.25 \pm 0.88 \\
\mathrm{c}\end{array}$ & $\begin{array}{c}12.627 \pm 0.9 \\
1 \mathrm{c}\end{array}$ & $\begin{array}{c}6.62 \pm 0.91 \\
\text { bc }\end{array}$ & $\begin{array}{c}74.37 \pm 4.43 \\
\mathrm{c}\end{array}$ & S \\
\hline $550 \% \mathrm{UBF}$ & $\begin{array}{c}10.12 \pm 1.12 \\
\mathrm{~d}\end{array}$ & $\begin{array}{c}11.12 \pm 0.83 \\
\mathrm{c}\end{array}$ & $\begin{array}{c}10 \pm 1.06 \\
\mathrm{c}\end{array}$ & $\begin{array}{c}10.25 \pm 0.88 \\
\mathrm{c}\end{array}$ & $\begin{array}{c}10.25 \pm 0.7 \\
\mathrm{~d}\end{array}$ & $\begin{array}{c}11.12 \pm 1.45 \\
\mathrm{~d}\end{array}$ & $\begin{array}{c}6.37 \pm 1.06 \\
\mathrm{c}\end{array}$ & $\begin{array}{c}69.25 \pm 3.24 \\
\mathrm{~d}\end{array}$ & S \\
\hline L.S.D & 1.88 & 1.81 & 1.87 & 2.29 & 1.76 & 1.82 & 1.68 & 7.36 & \\
\hline
\end{tabular}

Values followed by the different letter in the same column are significantly different $(p<0.05)$

UBF: unripe banana flour VG: Very good G: Good S: Satisfactory

Table 11. Chemical composition of flat bread containing wheat flour with or without different levels of unripe banana flour.

\begin{tabular}{|c|c|c|c|c|c|c|}
\hline $\begin{array}{l}\text { Parameters } \\
\text { Bread samples }\end{array}$ & $\begin{array}{c}\text { Moisture } \\
\% \\
\end{array}$ & $\begin{array}{c}\text { Crude } \\
\text { protein } \%\end{array}$ & $\begin{array}{c}\text { Fat } \\
\%\end{array}$ & $\begin{array}{c}\text { Ash } \\
\%\end{array}$ & $\begin{array}{c}\text { Crude fiber } \\
\%\end{array}$ & $\begin{array}{c}\text { Total } \\
\text { Carbohydrate*\% }\end{array}$ \\
\hline Wheat flour $72 \%$ (control) & 39.02 & 9.03 & 2.74 & 1.60 & 0.40 & 86.23 \\
\hline $10 \% \mathrm{UBF}$ & 39.19 & 8.61 & 2.61 & 1.79 & 1.03 & 85.96 \\
\hline $20 \% \mathrm{UBF}$ & 39.23 & 8.06 & 2.28 & 1.78 & 1.61 & 86.27 \\
\hline $30 \% \mathrm{UBF}$ & 39.69 & 7.99 & 2.14 & 1.87 & 2.29 & 85.71 \\
\hline
\end{tabular}

UBF: Unripe banana flour.

* Total carbohydrates was calculated by differences.

The chemical composition of flat bread containing wheat flour with or without different levels of unripe banana flour are presented in Table (11). The results indicated that control flat bread sample has $39.02 \%$ moisture, in compared with other bread samples No. 1, 2 and 3 which recorded 39.19, 39.23 and 39.69\% , respectively.

Crude protein and fat were high in control flat bread sample $(9.03 \%$ and $2.74 \%$ ), Followed by samples No $1(8.61 \%$ and $2.61 \%)$, sample No2 $(8.06 \%$ and $2.28 \%$ ) and sample No 3(2.99 and 2.14).
In the same Table (11) sample No 3 had a high content of ash and crude fiber which recorded $1.87 \%$ and $2.29 \%$ while the lowest amount of ash and crude fiber were recorded $1.60 \%$ and $0.40 \%$ in control sample.

On the other hand, total carbohydrates decreased in processed flat bread samples compared with control sample. They recorded $(86.23,85.96,86.27$ and 85.71) for control, sample No. (1), (2), and (3) respectively.

It could be seen that the contents of crude protein and fat were slightly decreased with the increasing levels 
of unripe banana flour. While moisture, ash, crude fiber and total carbohydrate were slightly increased.

Data illustrated in Table (12) showed that resistant starch of flat bread made from wheat flour $72 \%$ (control) replacing with unripe banana flour at $10 \%, 20 \%$ and $30 \%$. From Table (12) it can be concluded that sample No3 had highest content of resistant starch which recorded $21.02 \%$ while control sample had a lowest content of resistant starch which recorded $6.33 \%$ flowed by sample Nol and No 2 which recorded $11.19 \%$ and $18.62 \%$,respectively.

Table 12. Resistant starch content of flat bread made from wheat flour with or without different levels of unripe banana flour

\begin{tabular}{lcc}
\hline Bread samples & Resistant starch \% \\
\hline Wheat flour $72 \%$ (control) & 6.33 \\
1 & $10 \%$ unripe banana flour & 11.19 \\
2 & $20 \%$ unripe banana flour & 18.62 \\
3 & $30 \%$ unripe banana flour & 21.02 \\
\hline
\end{tabular}

Data in Table (13): showed that the effect of replacement wheat flour with unripe banana flour on texture properties of processed flat bread samples such as hardness, springiness, gumminess and chewiness

The results indicated that springiness, gumminess and chewiness parameters of control sample was the highest $0.19,20.67$ and 3.82 (N)respectively. While the highest hardness recorded in sample (2) $(21.26 \mathrm{~N})$.

Table 13. Texture analysis of flat bread made from wheat flour with or without different levels of unripe banana flour.

\begin{tabular}{|c|c|c|c|c|}
\hline $\begin{array}{l}\text { Parameters } \\
\text { Bread } \\
\text { samples }\end{array}$ & $\begin{array}{l}\text { Hardness } \\
\text { (N) }\end{array}$ & $\begin{array}{l}\text { Springiness } \\
\text { (N) }\end{array}$ & $\begin{array}{c}\text { Gumminess } \\
\text { (N) }\end{array}$ & $\begin{array}{c}\text { Chewiness } \\
\text { (N) }\end{array}$ \\
\hline control & 21.04 & 0.19 & 20.67 & 3.82 \\
\hline $120 \% \mathrm{UBF}$ & 21.14 & 0.18 & 20.43 & 3.06 \\
\hline $2 \quad 30 \% \mathrm{UBF}$ & 21.26 & 0.16 & 20.01 & 2.77 \\
\hline
\end{tabular}

\section{CONCLUSION}

Unripe Banana flour could be added to products (cupcakes and flat bread) up to the level of 30\% without any great significant change in organoleptic characteristics development of such functional foods not only improves the nutritional status of the general population but also helps those suffering from degenerative diseases associated with today's changing life styles and environment

\section{REFERENCES}

A.A.C.C(1994).Aproved Method of American Association of cereal Chemists published by American Association of cereal Chemists Inc.st paul, Minnesota, U.S.A

A.O.A.C. (2007). Official Method of Analysis. Association of Official Analytical Chemists Washington DC, USA.

Acvedo, E.A.; Hernandez, J.J.I.; Vargas, G.P.; Diaz, P.O.; Perez, L.A.B.(2012). Starch digestibility and glycemic index of cookies partially substituted with unripe banana flour. Food Science and Technology, Cambridge, v.46, n.1, p.177-182,
Al-Dmoor, H.M. (2012) Flat Bread Ingredients and Fortification. Quality Assurance and Safety of Crops and Foods, 4,2-8. properties of Sweet and Potato Chips. Nigeria Food Journal 28 (2), 448

Aparicio-Saguilán, A; Sáyago-Ayerdi, S. G; VargasTorres, A; Tovar,j; Ascencio-Otero,T.A; and BelloPérez,L.A.(2007). Slowly digestible cookies prepared from resistant starch-rich lintnerized banana starch. Food Composition and HYPERLINK "http://www.sciencedirect.com/science/journal/0889 1575"Analysis.vol 20 (3-4) 175:181.

Bhatawale, S.P. ; Mohammad, U.I.A., Mirza, R.S.S., Mohammed Zafar, I.M., Siddiqui, A.N. and Mehraj Fatema, Z.M. (2012). Effect of unripe banana flour incorporation on resistance starch content of rice papad. Nutrition Food Science 2(5): 1-3.

Bezerra,C.V; Da cruz rodrigues,A.M; Amante,E.R,and DA Silava,L.H.M.(2013). Nutritional potential of green banana flour obtained by dring in spouted bed OFRev. Bras. Frutic.,Jaboticabal - SP, v. 35, n. 4 , p. $1140-11$

Boutros, I. (2013). Reducing risks Wheat supply in Egypt.Retrievedfromhttp://www.dailynewsegypt. com/2013/05/27/reducing-risks-wheat-supply-inegypt

Dubat A (2010) A new AACC international approved method to measure rheological properties of a dough sample. Cereal Foods World 55: 150

Englyst, H., S.M. Kingman and J.H. Cummings. (1992). Classification and measurement of nutritionally important starch fractions. Eur. J. Cli. Nutr. 46: 3350

Eerlingen, R. C.; van Haesendonck, I. P.; de Paepe, G. and Delcour, J. A. (1994). Enzyme-resistant starch. III. The quality of straight-dough bread containing varying levels of enzyme-resistant starch. Cereal Chemistry. 71(2): 165-170.

El-Farra, A. A.; Korshid, A. M., Mansour, S. M., and Galal, A. M. (1982). Studies on the possibility of supplementation of balady bread with various commercial soy-products. 1st., Egypt. Conf. on Bread Research.

El Marassy s.s, Basyony .a .e, Abed EL Megeid a.e and Mustafa A.E.M(2016) Effect of Supplemented Bread with Unripe Banana Flour on Obese Rats Suffering From Diabetes Environment and Biological Sciences 28-29, 2016

Faridi, H. A. and Rubenthaler, G. L. (1984). Effect of baking time and temperature on bread quality, starch gelatinization, and staling of Egyptian balady bread. J. Cereal Chem. 61(2): 151.

Gazette, S. (2013). Egypt remains world's largest wheat importer Retrieved from. http:// english. alarabiya.net/en/business/economy/2013/07/07/Egyp t-remains-world-s-largest-wheat-importer.html

Gomes,M. Ronda.F. Caballero,P.A. Planco,c.a and Rosell,C.M.(2006).functionality of different hydrocolloids on the quality and shelf-life of yellow layer cakes. Science direct 21:167-173 
Hafez, A.A. (2012) Physico-Chemical and Sensory Properties of Cakes Supplemented with Different Concentration of Marjoram. Australian Journal of Basic and Applied Sciences, 6, 463-470.

Juarez-Garcia, E.; Agama-Acevedo, E.; Sayago-Ayerdi, S.G.; Rodriguez-Ambriz, S. L. and Bello-Perez, L. A. (2006). Composition, digestibility and application in breadmaking of banana flour. Plant Foods for Human Nutrition, 61, 131-137.

.Menezes,E. W; Tadini, C.C; Tribess, T.B; Zuleta, A; Binaghi,J; Pak,N; Vera,G; Dan,M.C.T;. Bertolini, A .C; Cordenunsi, B. R; and Lajolo, F. M. (2011). Chemical Composition and Nutritional Value of Unripe Banana Flour (Musa acuminata, var. Nanicão). Plant foods for human nutrition. vol 10.1007/s11130-011-0238-0

Norhidayah, M., *Noorlaila, A. and Nur Fatin Izzati, A.(2014) Textural and sensorial properties of cookies prepared by partial substitution of wheat flour with unripe banana (Musa x paradisiaca var. Tanduk and Musa acuminata var. Emas) flour International Food Research Journal 21(6): 2133-2139

Pacheco-Delahaye, E. and Testa, G.( 2005). Evaluacion nutricional fisica y sensorial of panes of trigo y platano verde. Interciencia 30: 300-304
Ritthiruangde,P. Parnbankled,S. Donchedee,S and Wongsagonsup ,R(2011) Physical, Chemical, Textural and Sensory Properties of Dried Wheat Noodles Supplemented with Unripe Banana Flour. Kasetsart J. (Nat. Sci.) $45: 500-509$

Seleem, H.A. and Omran, A.A. (2014) Evaluation Quality of One Layer Flat Bread Supplemented with Beans and Sorghum Baked on Hot Metal Surface. Food and Nutrition Sciences, 5, 2246-2256

Steell, R.G. and Torrie, J.H. (1980). Principles and procedures of statistics. 2 ed. Mc-Grow-Hill, New York, USA, pp.120-150.

Tiboonbun,W.; Sungsri-in. $M$ and Moongngarm.A; (2011) Effect of Replacement of Unripe Banana Flour for Rice Flour on Physical Properties and Resistant Starch Content of Rice Noodle. World Academy of Science, Engineering and Technology.vol 572011

Zuleta, A., Binaghi, M.J., Greco, C.B., Aguirre, C., De la Casa, L., Tadini, C. and Ferrer, P.A.R. (2012). Diseño de panes funcionales a base de harinas no tradicionales. Revista Chilena de Nutrición 39: 5864.

\footnotetext{
التقييم الفيزيوكيميائي والحسي لبعض منتجات المخابز المدعمة بدقيق الموز الغير ناضج كمصدر للتشا المقاوم

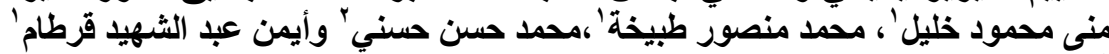

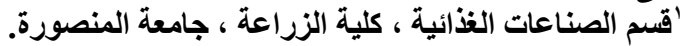

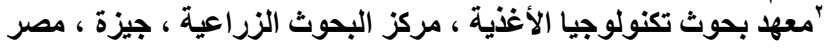

يحتوي دقيق الموز الغير ناضج علي نسبه عالية من المركبات الغير قابله للهضم مثل النشا المقاوم والسكريات غير النشوية ولذلك التك

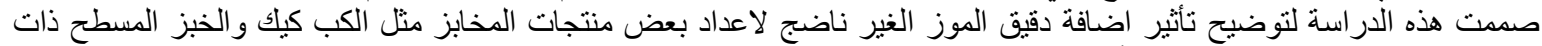

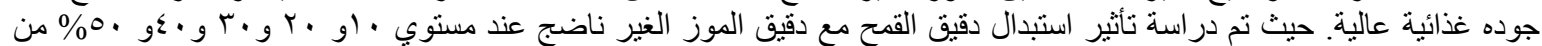

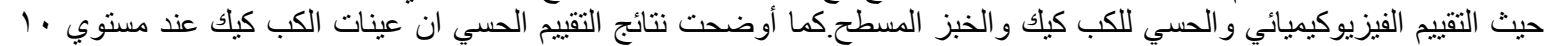

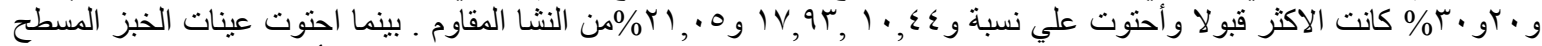

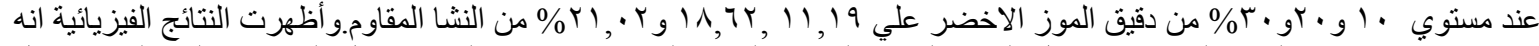

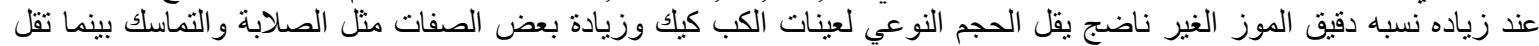

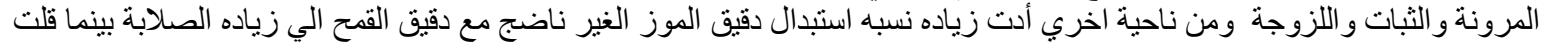

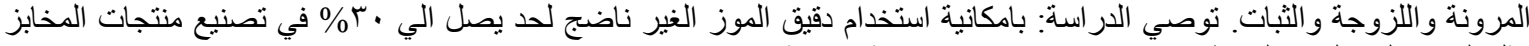

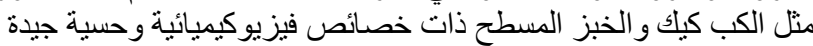

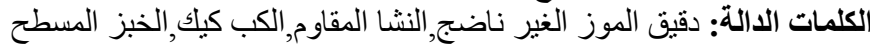

